\title{
The Influence of Madrasah Teacher Leadership Competence and Motivation on Teacher Performance in MIN 2, Palembang City
}

\author{
Tri Yani Guta ${ }^{1 *}$, Happy Fitria ${ }^{2}$, Achmad Wahidy ${ }^{2}$ \\ ${ }^{1}$ MIN 2 Palembang City, South of Sumatera, Indonesia \\ ${ }^{2}$ Universitas PGRI, Palembang, Indonesia \\ *Corresponding author.Email: gutatriyani@gmail.com
}

\begin{abstract}
The aim of this study is to see if there is an impact of madrasah principal leadership, competence, and motivation on teacher performance at Min 2 Palembang city. The tool used in this study involves descriptive quantitative with a survey approach to assess the population and sample in the study, which was conducted in a single way with a population of 75 and a sample of 50 teachers. Multiple linear regression with simultaneous and partial experiments was used in the data analysis methodology. According to the findings of this report, 1) the leadership variable of madrasah principals has a significant influence on teacher performance variables; 2) the teacher competency variable has a significant influence on teacher performance variables; and 3) the motivation variable has a significant influence on teacher performance variables.
\end{abstract}

Keywords: Leadership, Competence, Motivation, Performance

\section{INTRODUCTION}

In implementing madrasah-based management effectively and efficiently, it requires a madrasah principal who has leadership skills, planning, and a broad view of madrasah and education. The authority of the head of madrasa must be developed by increasing caring attitude, enthusiasm for learning, work discipline, exemplary and human relations as the capital to embody a conducive working climate, the success of the organization in achieving the stated goals will depend heavily on the role of leadership. Likewise, leadership plays a very central role in the dynamics of organizational life. This is in accordance with the opinion of [1].

According to the findings of Lian's previous study [2], there is a significant influence of leadership on work commitment, no impact of work motivation on work commitment, and competence has a significant influence on work commitment.

Based on observations made, the conditions seen in MIN 2 Palembang City, how teacher competence should be a concern, one of which is the availability of teachers who are competent and in accordance with their fields, which is still limited. There are some teachers who still have to be motivated to comply with the regulations applied in school and the teacher's performance is not optimal in completing school assignments, and the motivation of the principal to the staff and teachers who are given has not been able to improve the performance of teachers in educational institutions in schools. The verification results for hypothesis 2 revealed the relationship between work motivation and organizational commitment shown from the $t$ value and the likelihood value which indicates that there is a significant and positive relationship between work motivation and organizational commitment with a significant value $(0.000 .05)$ conducted by Arafat dan Haryono [3].

From the description above, the writer needs to do a research entitled " The Influence of Madrasah Teacher Leadership Competence and Motivation on Teacher Performance in MIN 2, Palembang City ".

Leadership is essentially a science and art to influence and direct others by building obedience, loyalty, trust, respect and collaborating passionately in achieving goals [4].

Leadership can also be defined as the process of influencing or setting an example by leaders to followers in an effort to achieve organizational goals [5].

The principal is a determinant of success in the organization of a Madrasah based on what is expected, the duties and functions are very heavy, so that good is needed with the stakeholders who are in the scope of 
education, in order to produce the desired results collectively. The implementation of daily tasks must be accompanied by a clear vision and mission as the first step in running an organization [6].

Competence is characterized as a fusion of intelligence (thinking power), attitude (heart power), and skills (physical power) manifested in the form of actions. Competence may also be defined as a combination of abilities, knowledge, skills, attitudes, traits, comprehension, respect, and expectations underlying a person's characteristics [7].

In this case, teachers who carry out work at educational institutions are required to have these qualifications that guarantee expertise, proficiency or proficiency as professional educators. These mandatory criteria are quality standards that must be met by teachers. Professional teachers who meet these standards are a supporter of the creation of a quality person. teachers in carrying out their work. In order to carry out their profession, the teaching staff, especially in this case the teacher really needs a variety of knowledge [6].

Based on the opinions of several experts above, it can be concluded that competence is the competence of the ability or skills a person has, and the fusion of intelligence (thinking power), attitude (heart power), and abilities (physical power) manifested in the form of acts in the performance of a job or mission. In a sector, the location they occupy is determined by the position they occupy.

Motivation is a reason that becomes the basis for a person to achieve the goals that have been planned and set by an organization [7].

In essence, teacher success is a teacher's actions in generating and carrying out duties as an educator and teacher in the classroom in accordance with predetermined parameters [7].
Teacher success refers to a teacher's ability to carry out learning activities, from preparation to evaluating learning outcomes, the achievement of which is based on the ability to carry out obligations as a teacher [8].

Argues that teacher efficiency is a type of behavioral devices shown by a person during the learning process and is a description of the actions a person does during learning [9].

Ngiode [9] argues that teacher performance is a set of behavioral devices shown by a person during the learning process and is a description of the actions a person does during learning.

Teacher performance is the ability of a teacher to carry out learning tasks from planning to evaluation of learning outcomes, the achievement of which is based on the ability to carry out obligations as a teacher [8].

\section{METHODS}

This analysis was carried out at MIN 2 Palembang City during the odd semester of the academic year 20202021. The quantitative method was used in this study, which was conducted in July 2020. The merits of writing scientific papers are determined by methodology [10]. If the researcher wishes to learn about the influence or treatment of others, this approach may be used.

Based on the above, the population in this study consisted of all 73 teachers from MIN 2 Palembang, consisting of 12 men and 61 women. Population size is more or less than 100 , then the sampling is at least $50 \%$ of the population size. then the number of samples taken is $68 \%$ or 50 people randomly.

\section{RESULTS AND DISCUSSION}

Table 1. Simultaneous Test $X_{1}, X_{2}, X_{3}$ on $Y$ Coefficients $^{\mathrm{a}}$

\begin{tabular}{|c|c|c|c|c|c|c|c|c|}
\hline & \multirow{2}{*}{ Model } & \multicolumn{2}{|c|}{$\begin{array}{l}\text { Unstandardized } \\
\text { Coefficients }\end{array}$} & \multirow{2}{*}{$\begin{array}{c}\begin{array}{c}\text { Standardized } \\
\text { Coefficients }\end{array} \\
\text { Beta }\end{array}$} & \multirow{2}{*}{$\mathrm{T}$} & \multirow{2}{*}{ Sig. } & \multicolumn{2}{|c|}{$\begin{array}{c}\text { Collinearity } \\
\text { Statistics }\end{array}$} \\
\hline & & B & $\begin{array}{l}\text { Std. } \\
\text { Error }\end{array}$ & & & & Tolerance & VIF \\
\hline \multirow[t]{4}{*}{1} & (Constant) & 58.022 & 23.536 & & 2.465 & .017 & & \\
\hline & $\mathrm{X}_{1}$ & .092 & .132 & .099 & .695 & .491 & .985 & 1.015 \\
\hline & $X_{2}$ & .320 & .192 & .239 & 1.671 & .102 & .981 & 1.019 \\
\hline & $\mathrm{X}_{3}$ & -.024 & .121 & -.029 & -.200 & .842 & .990 & 1.010 \\
\hline
\end{tabular}

a. Dependent Variabel: $Y$ 
Based on data analysis using SPSS 22, the regression equation constant value $\alpha$ is 58.022 and the coefficient value of the independent variable $b_{1}$ is 0.092 , $b_{2}$ is 0.320 and. $b_{3}$ of 0.024 Then the calculation of the regression equation is as follows:

$$
\mathrm{Y}=\mathrm{a}+\mathrm{b}_{1} \mathrm{X}_{1}+\mathrm{b}_{2} \mathrm{X}_{2}+\mathrm{b}_{3} \mathrm{X}_{3}
$$

$$
\mathrm{Y}=58.022+0.092+0.320+0.024
$$

This means that the principal's leadership and principal's motivation has increased positively on teacher performance.

Table 2. Determination Test $X_{1}, X_{2}, X_{3}$ on $Y$

Model Summary

\begin{tabular}{|c|c|c|c|c|}
\hline Model & $\mathrm{R}$ & $\begin{array}{c}\mathrm{R} \\
\text { Square }\end{array}$ & $\begin{array}{c}\text { Adjusted R } \\
\text { Square }\end{array}$ & $\begin{array}{c}\text { Std. Error of the } \\
\text { Estimate }\end{array}$ \\
\hline 1 & $.890^{\mathrm{a}}$ & .792 & 779 & 2.087 \\
\hline
\end{tabular}

a. Predictors: (Constant), $\mathrm{X}_{1}, \mathrm{X}_{2}, \mathrm{X}_{3}$

According to the table above, the correlation coefficient is 0.890 or 8.90 percent, and the sum of influence can be seen from the Modified $R^{2}$ value of 0.792 or 7.92 percent, while the rest is affected by other variables not previously examined at 0.779 or 7.79 percent.

The independent variable (independent) of madrasah leadership $\left(\mathrm{X}_{1}\right)$ has a significant impact on the dependent variable (dependent) teacher results (Y). As can be seen from the results of the multiple linear regression test, the significance value of 0.017 in the regression test table is less than 0.05 , implying that the principal's leadership has a positive impact on teacher success.

The dependent variable (dependent) teacher output is significantly influenced by the independent variable (independent) competence $\left(\mathrm{X}_{2}\right)(\mathrm{Y})$. The regression test table also shows that the significance value of 0.000 is less than 0.05 , implying that competence has a positive impact on teacher results.

The independent variable (independent) teacher motivation $\left(\mathrm{X}_{3}\right)$ has a significant effect on the dependent variable (dependent) teacher performance (Y). The regression test table also shows that the significance value of 0.014 is less than 0.05 , implying that competence has a positive impact on teacher results.

The regression test results show that each independent variable of madrasah principal leadership $\left(\mathrm{X}_{1}\right)$, competence $\left(\mathrm{X}_{2}\right)$, and teacher motivation $\left(\mathrm{X}_{3}\right)$ has a significance value less than 0.05 , so it can be inferred that the three independent variables both have a substantial or positive impact on the dependent variable on $(\mathrm{Y})$

The estimation of the significance value obtained from each independent variable of the principal of madrasah $\left(\mathrm{X}_{1}\right)$, competence $\left(\mathrm{X}_{2}\right)$, and principal motivation $\left(\mathrm{X}_{3}\right)$ has a value less than 0.05 , so it can be concluded that of the three independent variables, all have a substantial or positive impact on the dependent variable on teacher performance (Y). That is, the better the madrasah principal's leadership, the better the teacher's performance; similarly, if the encouragement provided by the principal to the teacher is so good, the teacher's performance results would improve.

\section{CONCLUSION}

The results of this study indicate that the calculation of the coefficients table, the significant value for the leadership variable of madrasah principals is 0.017 $<0.05$, so Ho is rejected or Ha is accepted. Thus, it can be concluded that the leadership variable of madrasah principals has a significant influence on teacher performance variables, the coefficients table calculation shows that the significant value for the teacher competency variable is $0.000<0.05$, so Ho is rejected or $\mathrm{Ha}$ is accepted. Thus, it can be concluded that the teacher competency variable has a significant influence on the teacher performance variable, the calculation of the coefficients table obtained a significant value for the teacher motivation variable is $0.014<0.05$, then Ho is rejected or $\mathrm{Ha}$ is accepted. Thus, it can be concluded that the motivation variable has a significant influence on teacher performance variables.

\section{ACKNOWLEDGMENT}

Our deepest gratitude goes to Teachers in MIN 2 Palembang City, Chancellor of Palembang PGRI University, Director of the Postgraduate Program of PGRI Palembang University and the Education Management Study Program of PGRI Palembang University, who have supported us in doing this extraordinary thing. This project is funded independently. We also want to thank our Education Management friends who helped us a lot in a short time frame to complete this project. 


\section{REFERENCES}

[1] Kristiawan, M., Safitri, D., \& Rena L. (2017). Education Management. Yogyakarta: Deepublish.

[2] Lian, B. (2014). The Influence of Leadership, Work Motivation and Competence on Work Commitment and Its Implications on Employee Performance in Regional Work Units (SKPD) in Palembang City. Doctoral Dissertation of the University of Persada Indonesia, Y.A.I.

[3] Arafat, Y., \& Haryono, S. (2017). Effects of Organizational Culture ang Work Motivation on Job Performance Among the Private University Fulltime Fakulties in South Sumatra Province. (X2) volume 20. International Information Institute. Master of Program Management, Post Graduate School, (Muhammadiyah University of Yogyakarta).

[4] Susanto, A. (2018). Concept, Strategy, and Implementation of Teacher Performance Improvement Management, Second Edition, Depok: Prenadamedia group.

[5] Dwi. (2016). Understanding Leadership in General. https://umumpengentuk.blogspot.com/2016/01/pengentukkepemimpin-secara-umum-adalah.html, accessed on March 16, 2020, at 12.25 WIB

[6] Fitria, H. (2018). The Influence of Organizational Culture and Trust Through the Teacher Performance in The Private Secondary School in Palembang. International Journal of Scientific \& Technology Research, 7 (7).

[7] Ibeng, P. (2020). Definition of Motivation, Types, Factors, and According to Expert Expert. https://pend Pendidikan.co.id/pengentuk-motifjenis-faktor-dan-menurut-para-ahli/ accessed on 14 April 2020, at 08.10 WIB.

[8] Rachmawati, Y. (2013). The Influence of Principal Leadership on Teacher Performance, Volume 1. Journal of Economics Education Student at IKIP Veteran Semarang

[9] Ngiode, S. (2016). The Influence of Principal Leadership, Work Motivation and Work Discipline on Teacher Performance at MTs.N Batudaa, Gorontalo District. Volume 4. Journal of Islamic Education Management.

[10] Muttaqin, K., \& Rahmadoni, J. (2020). Analysis and Design of File Security System AES (Advanced Encryption Standard) Cryptography Based. Journal of Applied Engineering and Technological Science (JAETS), 1(2), 113-123. https://doi.org/10.37385/jaets.v1i2.78 